\title{
Historical mine pollution and environmental resilience: biomineralization processes and biogeochemical barriers
}

\author{
Giovanni De Giudici ${ }^{1, *}$, Daniela Medas ${ }^{1}$, Rosa Cidu $^{1}$, Pierfranco Lattanzi ${ }^{1}$, Francesca \\ Podda $^{1}$, Nicola Rigonat ${ }^{1}$, Pier Andrea Marras ${ }^{1}$, Richard B. Wanty ${ }^{2}$, Briant Kimball ${ }^{3}$, and \\ Robert L. Runkel ${ }^{4}$ \\ ${ }^{1}$ Department of Chemical and Geological Sciences, University of Cagliari, via Trentino 51, 09127, \\ Cagliari, Italy \\ ${ }^{2}$ U.S. Geological Survey, MS 963 Denver Federal Center, Denver, CO 80225 \\ ${ }^{3}$ U.S. Geological Survey, 2329 W Orton Circle, Salt Lake City, Utah, 84117 \\ ${ }^{4}$ U.S. Geological Survey, Colorado Water Science Center, 3215 Marine St, Boulder Colorado, 80303
}

\begin{abstract}
Three streams in SW Sardinia were studied to evaluate the transport of metals in the environment, and to characterize the natural processes that lead to decreased metal loads. Here we focus on $\mathrm{Zn}$. Although the metal load varies by 2-3 orders of magnitude, we have observed natural biologically mediated attenuation processes, including uptake by vegetation and biomineralization. In this paper, we review the chemical and physical processes that lead to natural $\mathrm{Zn}$ attenuation, and discuss the merits of mimicking those processes when designing remediation schemes.
\end{abstract}

\section{Introduction}

Mine activity can impact the quality of soil, water and air, causing critical changes to the environment. It is estimated that mine-related pollution in the EU, USA, and China affects about $0.1 \%$ of the land surface $[1,2]$. Mine pollution, even if it is not a specific cause of global changes, has a global dimension [3, 4]. A major impact from mining is represented by the dispersion of a huge volume of mining-related waste material towards the oceans. These wastes include fine-grained materials whose reactivity is large (e.g. metal sulphide in contact with oxygenated water), and whose alteration causes an increase of metal and contaminant bioavailability. In historic mines, the interaction between water, sediments, gas and biosphere may lead to natural remediation decades or centuries after closure. These processes are of interest in the context of monitoring the environment at local and global scales and devising remediation technologies for mine related contaminants based on natural abatement processes. This work considers some case histories from Sardinia mine districts from the catchment scale down to the molecular scale.

\footnotetext{
* Corresponding author: gbgiudic@unica.it
} 


\section{Historical sites in Sardinia}

The study area (Fig. 1) includes the Iglesiente and Arburese districts (southwestern Sardinia), where mine activity started in pre-Roman times, boomed in the $1850 \mathrm{~s}$ with intensive industrial-scale exploitation, and ceased in the 1990s. The Iglesias district extends over an area of about $120 \mathrm{~km}^{2}$. Base-metal $(\mathrm{Zn}, \mathrm{Pb}, \mathrm{Ag})$ sulphides, barite ores, and calamine $(\mathrm{Zn}, \mathrm{Pb})$ deposits were exploited at over 40 mines [5 and references therein; 6, 7], leaving a large volume (more than $70 \mathrm{Mm}^{3}$ ) of mine residue across local landscapes. The Arburese district comprises the large Montevecchio-Ingurtosu $\mathrm{Pb}-\mathrm{Zn}-\mathrm{Ag}$ district $[8$ and references therein]. Here too abandoned mine tailings and flotation muds make up huge waste piles. Both areas have been affected by erosion for centuries, causing dispersion of an unknown amount of mine residues to rivers and eventually to the Mediterranean Sea [9-11].

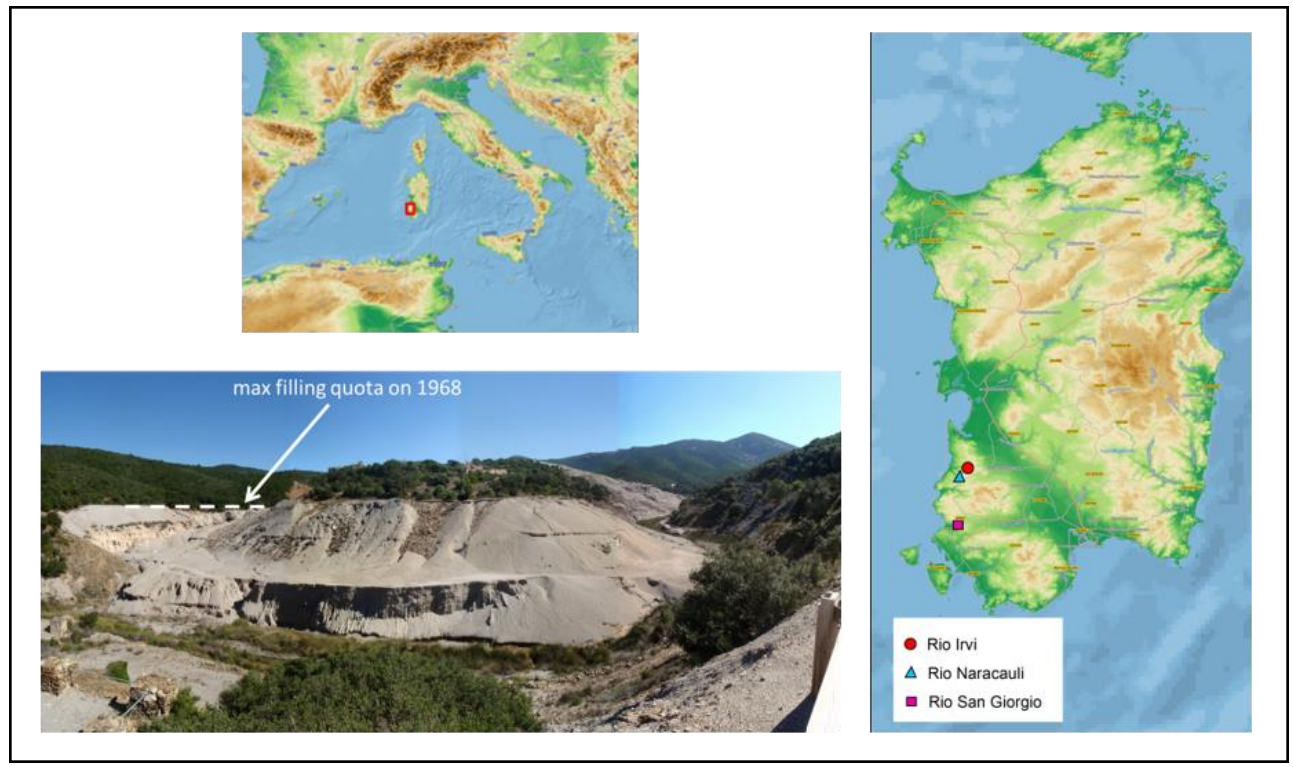

Fig. 1. Location of the study sites in southwestern Sardinia and photograph of the deeply eroded mine tailings at Ingurtosu in the Naracauli valley.

The object of the study were three streams flowing through the mine areas: Rio San Giorgio, which originates near the town of Iglesias; Rio Naracauli, that originates from the Ingurtosu mine, and Rio Irvi, which flows through the Montevecchio mining district; most of its water comes from the Casargiu adit outflow, with only minor contributions from streams draining mine dumps or tailings [12].

\section{Methods}

Our tracer-dilution method of stream study involved several steps: (i) characterizing the stream; (ii) injecting salt solution, (iii) monitoring the approach to steady-state concentration of the salt tracer in stream water, (iv) sampling during the steady state flow and (v) modelling the results. The Rio Naracauli was sampled at end of May 2011, the Rio Irvi at the beginning of June 2011, and the Rio San Giorgio at the beginning of June 2012. The synoptic sampling took place over a few hours and resulted in a spatially-dense assemblage of samples, with usually no more than $100 \mathrm{~m}$ between sample stations. Full details have been reported previously [11-15]. 
Mineral and microscopic analysis in this work were conducted by X-ray Powder Diffraction (XRPD), Scanning Electron Microscopy (SEM), and synchrotron-based techniques such as X-ray Absorption Spectroscopy (XAS) and Scanning Transmission Xray Microscopy (STXM) [15-18].

\section{Results and discussion}

In previous work, we investigated three different rivers affected by mine pollution. The metal load of these rivers changes by orders of magnitude (Fig. 2). Particularly, Zn load in Rio Irvi exceeds $1800 \mathrm{~kg} / \mathrm{day}$, while $\mathrm{Zn}$ load in Rio Naracauli and Rio San Giorgio is around 30 and $5 \mathrm{~kg} /$ day, respectively. The maximum load occurs in Rio Irvi, where flow from the Casargiu mine adit started in 1997. Besides the short time spanned from the beginning of pollution, Rio Irvi is also characterized by erosional processes and almost no vegetation growing in its riverbed.

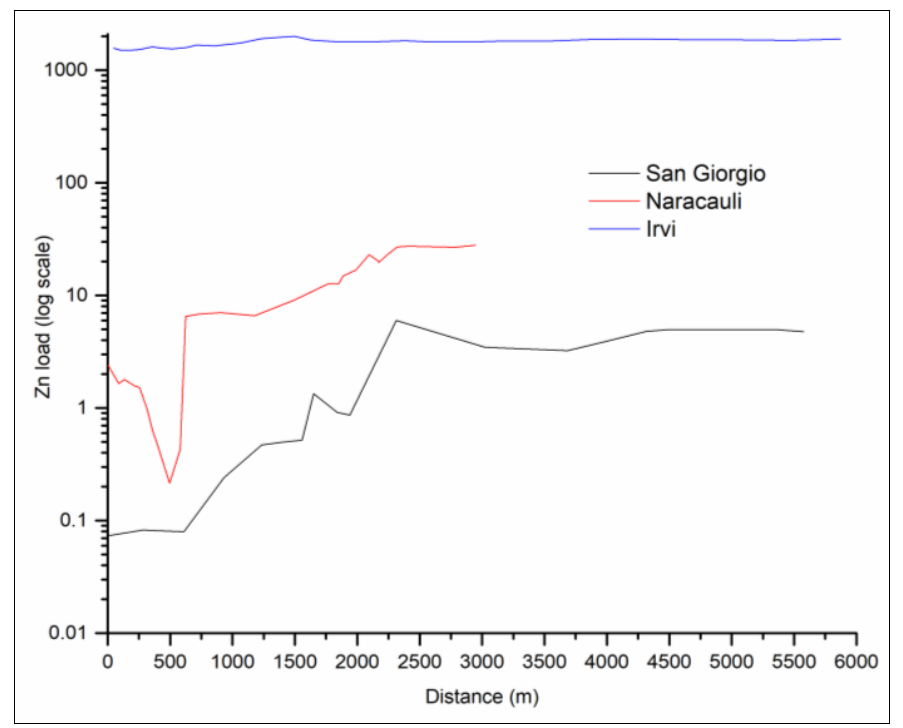

Fig. 2. Comparison of $\mathrm{Zn}$ concentrations (in log scale) in the Rio San Giorgio, Rio Naracauli, and Rio Irvi.

Natural attenuation processes of river metal loads were investigated through microscopic techniques. Interestingly, two distinct microbial films were found in Rio Naracauli that control biomineralization processes and form hydrozincite and a hemimorphite-like phase. These biominerals are effective in the abatement of the aqueous $\mathrm{Zn}$ load. In Rio San Giorgio, where very dense vegetation characterizes the riverbed morphology and favors the sedimentation, extensive biologically-mediated formation of metal sulphides, namely framboidal pyrite (Fig. 3) and sphalerite, was observed by SEM analysis. Furthermore, XAS and STXM analysis (Fig. 3) on several plant tissues and rhizosphere materials of Juncus acutus and Phragmites australis, that dominate the riverbed vegetation in the study area, show that these plants promote $\mathrm{Fe}$ and $\mathrm{Zn}$ biomineralization through formation of biominerals such as iron oxides, hydrozincite, hemimorphite, Zn-cysteine and hydroxyapatite [15, 17, 19]. These biomineral phases are intrinsically linked to biological mediation in response to heavy metal pollution from abandoned mines. 

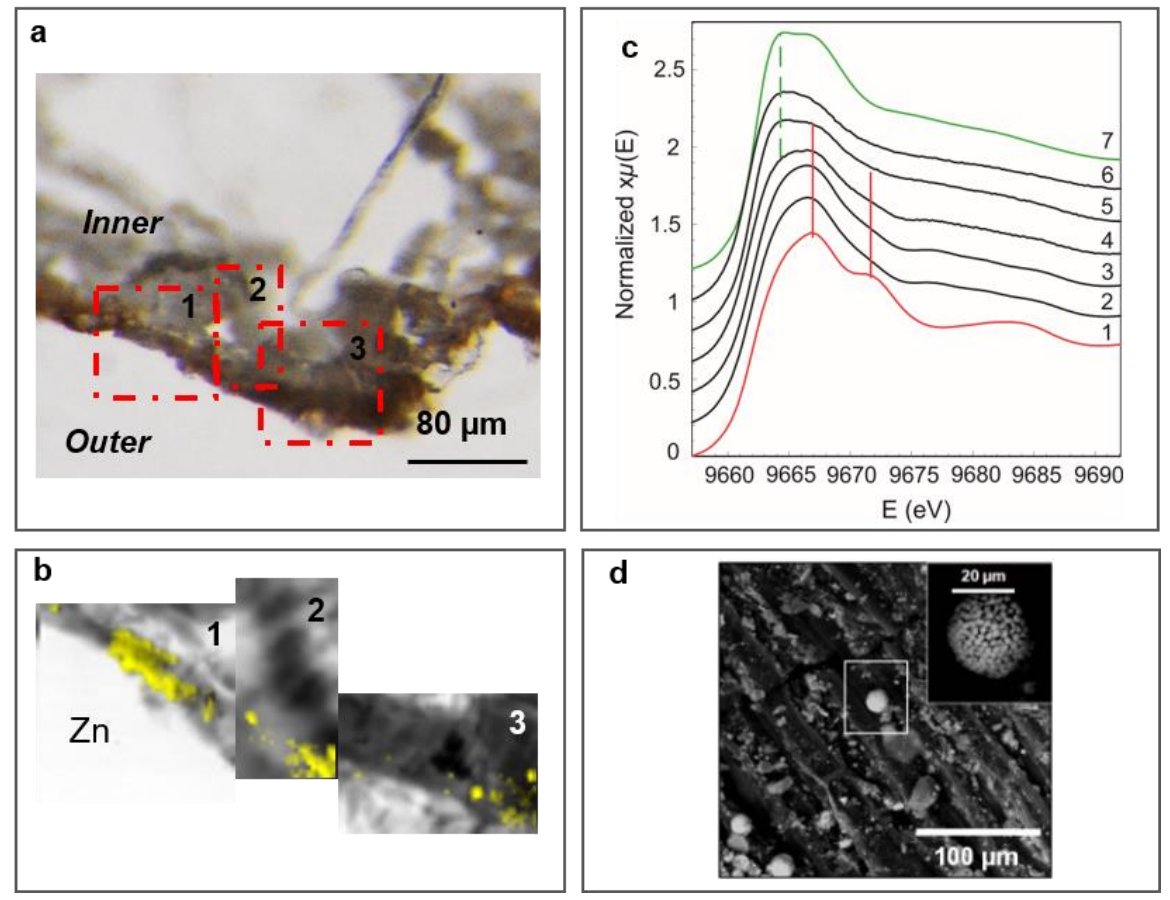

Fig. 3. Thin cross root section $(14 \mu \mathrm{m})$ of Phragmites australis collected along Rio San Giorgio (a and b). Ordinary light stereo-microscope image (a) and areas $(1,2,3)$ for LEXRF mapping. Bright field (absorption) images and LEXRF maps of Zn (b). XANES spectra (c) at the Zn K-edge collected on selected reference compounds (1: hydrozincite; 7: Zn hydroxyapatite), rhizosphere materials (2), external root cleaned (3), leaves (4), inner root (5), and stem (6) of Phragmites australis vertically shifted for the sake of clarity. SEM image of framboidal iron sulphide (d) on root of Phragmites australis.

A better knowledge of how and when metals become bioavailable to the biosphere are central to understand the environmental impact of metals. In the case of San Giorgio river, the long-time impact already activated resilience processes able to lower the availability of metals to the environment. At Naracauli river some biomineral processes are noticeably active. Besides the relevance to fundamental science, these biomineralization processes are central to shed light on natural processes responsible for sequestering metals. In the three rivers investigated by our group, these natural abatement processes have characteristics specific to each of the three sites. Understanding the complex interrelations between hydrology, mineralogy, geochemistry, microbes and plant mediation is crucial to develop cost-effective technology for remediation exploiting resilience processes like the observed biogeochemical barriers.

GDG received funding from FdS-RAS (F72F16003080002). RBW and BK received funding from the US Geological Survey's Mineral Resources and Toxics Substances Hydrology Programs.

\section{References}

1. B.F. Arbogast, et al., U.S. Geological Survey Circular 1191, 28 (2000)

2. G.C.S. Lin, S.P.S. Ho, Land Use Policy, 20, 87-107 (2003)

3. M. Meybeck, R. Helmer, Palaeogeogr Palaeoclim Palaeoecol, 75, 283-309 (1989)

4. M. Meybeck, Phil Trans Royal Soc Lond B, 358, 1935-1955 (2003) 
5. G. Aversa, et al., Per Miner, 71, 201-218 (2002)

6. R. Cidu, L. Fanfani, Geochem Explor Env Anal, 2, 243-251 (2002)

7. M. Boni, Econ Geol, 98, 715-729 (2003)

8. D. Medas, et al., Appl Geochem, 27, 1814-1820 (2012)

9. D. Medas, et al., Bio-Geo Interactions in Metal-Contaminated Soils 31, 113-130, Springer Berlin (2012)

10. F. Frau, et al., Water Air Soil Pollut, 226, 226-255 (2015)

11. G. De Giudici, et al., Chem Geol, 384, 110-119 (2014)

12. G. De Giudici, et al., Appl Geochem, 96, $42-54$ (2018)

13. B.A. Kimball, et al., Appl Geochem, 17, 1183-1207 (2002)

14. B.A. Kimball, R.L. Runkel, Mine Water Environ, 28, 274-290 (2009)

15. G. De Giudici, et al., Appl Geochem, 76, 124-135 (2017)

16. G. De Giudici, et al., Environ Sci. Pollut Res, 22, 19352-19361 (2015)

17. D. Medas, et al., Env Sci Technol, 49, 1400-1408 (2015)

18. D. Medas, et al., Env Sci Pollut Res, 25, 36645-36660 (2018)

19. D. Medas, et al., J Hazard Mater, in press (2017) 